\title{
An introduction to the flora of the Milne Bay Archipelago
}

\author{
R. Johns ${ }^{1}$, O. Gideon ${ }^{2}$, J. Simaga ${ }^{3}$, T. Kuria ${ }^{3}$, G. Bagoera ${ }^{2}$
}

Key words

endemism

Milne Bay Archipelago

Papua New Guinea

\begin{abstract}
The term Milne Bay Archipelago is used to include Goodenough, Fergusson and Normanby Islands - collectively the d'Entrecasteau Islands, the islands of the Louisiade Archipelago, Missima, Rossel and Sudest Islands and the two northern islands, the Trobriands and Woodlark. All are very complex with many small islands, often unnamed. Due to their geographic isolation the islands have many endemic species. So far 139 have been described. Of particular interest is the genus Rosselia, collected only twice from Rossel Island. This monotypic genus was placed, with many questions, in the Burseraceae and its current position is uncertain. Another neoendemic genus in Milne Bay is Lamiodendendron. It is a coastal tree scattered on several islands and also coastally on the mainland of the Milne Bay Province. A single collection has been made from the Northern Province. The islands are very poorly known and with continuing collections more endemic species can be expected.
\end{abstract}

Published on 30 October 2009

\section{INTRODUCTION}

The Milne Bay Archipelago includes a series of larger islands Goodenough, Fergusson, and Normanby (collectively called the D'Entrecasteaux Islands); the northern chain of island groups -Trobriand and Woodlark; and the south-eastern chain - the Louisiade Archipelago - which includes Misima, Rossel, and Sudest. Within the archipelago there are thousands of smaller, often unnamed, islands. The vegetation includes mangrove and coastal rainforest, lowland tropical rainforest and lower montane rainforest. Higher altitude vegetation types are confined to the D'Entrecasteaux Islands. Mt Vinevo (Goodenough Island), the highest mountain in the archipelago, reaches a height of $2566 \mathrm{~m}$ (Table 1).

Several islands have extensive areas of limestone and ultramafic floras which are poorly collected. With the extension of mining activities plant species on the ultramafics are threatened with extinction.

\section{HISTORY OF BOTANICAL EXPLORATION}

The first European explorer to sight the d'Entrecasteaux Islands was Rear Admiral Bruny d'Entrecasteau in 1793. Early European settlement in the islands dates back to a group of missionaries who established a Catholic Mission station on Woodlark Island from 1854-1856. There are no records of any botanical specimens being collected during this period. Captain John Moresby visited the area in 1874.

Andrew Goldie made several trips to New Guinea, the first in 1876 , followed by several trips to Port Moresby and environs. In 1878 he visited Cloudy Bay and the Louisiade Archipelago. He collected around Port Moresby in 1879 and 1880. In 1882 he landed by boat on the west coasts of Fergusson and Normanby Islands. Live plants were sent to London and dried specimens to Melbourne for study by Ferdinand von Mueller (1896). George Brown collected in New Guinea from 1875 (Frodin \& Gressitt 1982).

\footnotetext{
1 Botanical Research Institute of Texas, Fort Worth, Texas, USA.

2 Herbarium, Biology Department, University of Papua New Guinea

${ }^{3}$ National Herbarium, Forest Research Institute, P.O. Box 314, Lae, Papua New Guinea.
}

William E. Armit commanded the Argus Expedition to British Papua (Papua New Guinea) in 1883. He was acting Government Agent for Rigo and Mekeo from July 1894 to January 1895 and sub-collector of Customs at Samarai (1895-1897). After his expedition to Mt Maneo (Dayman) from 23 March to 3 April he sailed to Port Moresby on the 'Merrie England'. Shortly after, in 1895, he returned to Goodenough Island for exploration of the mountains. The collections of Armit from Goodenough were sent to MEL for study by Ferdinand von Mueller.

The earliest official Government expeditions were made by staff under the direction of William MacGregor, Administrator of British New Guinea from 1890-1898. During his frequent trips around the archipelago on administrative duties in the late 1890s the government officers accompanying him made small, but important collections of plants. MacGregor sent these specimens to Von Mueller for some ten years. Following the death of Von Mueller the specimens were sent to the Royal Botanic Gardens, Kew. G.R. Le Hunte followed MacGregor as Administrator of British New Guinea in 1900. Le Hunte collected in the Milne Bay Archipelago in 1899-1902, visiting several localities including Goodenough Island (Poiana) and the southern coast of Normanby Island. The scientific results were published in the Annual Reports of British New Guinea (1890-1898).

In 1950 Mrs. M.J. van Steenis-Kruseman listed the D'Entrecasteaux and Trobriand Islands as a priority for plant collection because of their low collecting intensity (Van Steenis-Kruseman 1950). She did not discuss the Louisiade Archipelago. This dearth of collections was partly addressed by the 4th (1953) and 5th (1956) Archbold Expeditions and more recently by the collecting trips reported here. The 4th (Brass 1956) and 5th Archbold Expeditions were the first major botanical expeditions that included visits to the islands of Milne Bay organised by L.J. Brass. Len Brass, the leader and also the botanical collector for the expeditions to southeast Papua New Guinea, made extensive collections on Goodenough Island and small collections from Ferguson Island during the 4th Expedition and collected on the remaining islands of the Milne Bay Archipelago during the 5th Expedition. On these expeditions Brass was joined (briefly) by John Womersley and other staff from the National Herbarium, Lae.

(c) 2009 Nationaal Herbarium Nederland

You are free to share - to copy, distribute and transmit the work, under the following conditions:

$\begin{array}{ll}\text { Attribution: } & \text { You must attribute the work in the manner specified by the author or licensor (but not in any way that suggests that they endorse you or your use of the work). } \\ \text { Non-commercial: } & \text { You may not use this work for commercial purposes. }\end{array}$

Non-commercia:

No derivative works: You may not alter, transform, or build upon this work.

For any reuse or distribution, you must make clear to others the license terms of this work, which can be found at http://creativecommons.org/licenses/by-nc-nd/3.0/legalcode. Any of the above conditions can be waived if you get permission from the copyright holder. Nothing in this license impairs or restricts the author's moral rights. 
Another major source of botanical collections in New Guinea was the work of missionaries such as Rev. C. (Copland) King and Rev. N. Cruttwell. Several of the missionaries had special training in botany because of the potential importance of local plants for medicinal purposes. The inherent botanical knowledge of the village people of the region is potentially an important source of botanical information, but has been only partly documented. Good botanical collections are rarely made to accompany such studies of traditional plant uses. Without adequate specimens much of this information on traditional plant uses is of limited use.

\section{RECENT EXPLORATION}

A comprehensive inventory of the flora and vegetation of the islands started in October 2006, and so far has included several trips from the National Herbarium in Lae and by staff from the Herbarium of the University of Papua New Guinea and the Botanical Research Institute of Texas. As a background for this inventory, a list of all available plant collections from the Milne Bay Archipelago and their (preliminary) identifications was databased by the senior author. The database now includes over 6500 collections from the Milne Bay Archipelago, mostly vascular plants, but additions from previous collectors are still being made. Nearly half the vascular plant collections are not identified to below the genus. Table 1 presents a summary of this list.

Table 1 Geographical and plant diversity information from the major islands of the Milne Bay Archipelago.

\begin{tabular}{lrrrrrrrrrrr}
\hline & 1 & 2 & 3 & 4 & 5 & 6 & 7 & 8 & 9 & 10 & 11 \\
\hline Good. & 687 & 2566 & 1137 & 957 & 0.7 & 612 & 86 & 71 & 30 & 187 & 33 \\
Ferg. & 1437 & 2000 & 1021 & 972 & 1.5 & 308 & 47 & 113 & 42 & 202 & 32 \\
Norm. & 1040 & 1158 & 1477 & 951 & 1.1 & 516 & 37 & 185 & 46 & 168 & 43 \\
Mis. & 202 & 1050 & 518 & 486 & 0.5 & 125 & 23 & 53 & 11 & 87 & 26 \\
Sud. & 865 & 806 & 672 & 631 & 1.4 & 160 & 13 & 68 & 23 & 104 & 48 \\
Ros. & 262 & 838 & 742 & 715 & 3.6 & 187 & 16 & 97 & 35 & 148 & 56 \\
Trob. & 874 & 365 & 216 & 216 & 4.1 & 80 & - & 31 & - & 31 & 5 \\
Wood. & 873 & 225 & 410 & 408 & 2.1 & 119 & 2 & 27 & 1 & 30 & 9 \\
Totals & & & 6413 & 5636 & & 2207 & 957 & & & &
\end{tabular}

1 Area $\left(\mathrm{km}^{2}\right) ; 2$ highest altitude $(\mathrm{m}) ; 3$ total number of collections in the database; 4 number of vascular plant collections; 5 number of vascular plant collections per $\mathrm{km}^{2} ; \mathbf{6}$ number of collections not identified below the species level. - 7-9. Specimens known from a single island only. $\mathbf{7}$ Ferns, fern allies and gymnosperms; 8 dicotyledons; 9 monocotyledons. - 10 Number of species only recorded from a single island. Not endemics but can occur in other regions of New Guinea and the Solomon Islands; 11 Milne Bay Archipelago endemic species recorded from each island.

As a result of the recent expeditions nearly 100 new genera and species were added to the original number of 1200 genera/ species from Normanby Island in the database. The collections made around Sewa Bay (Normanby Island) in January/ February 2007 illustrates our poor knowledge of the local floras. Although Sewa Bay was the major collecting locality for Brass in 1958 (c. 2000 numbers), of the 250 additional collections made in 2007, nearly $60 \%$ are new records for Normanby.

Plant portraits taken by D. Mitchell from open savannah areas on the ultramafics to the northeast of Sewa Bay probably includes several new species and possibly a new genus in the Acanthaceae (K. Volason pers. comm.). These data highlight the importance of future expeditions. Many local endemics have been described most based on 1-2 collections (Appendix 1).

\section{RELATIONSHIPS BETWEEN THE ISLAND FLORAS}

A preliminary analysis of the distribution data of species on the islands of the Milne Bay Archipelago was made. The most closely related island floras were those of Normanby and Fergusson with 180 recorded species occurring on both islands. The next two closely related islands were Sudest and Rossel with 137 recorded species. Goodenough Island was next related to Normanby and Fergusson with an average of 135 species in common. These five islands had 102 species (on average) in common, Misima Island had 86 species on average in common with the previous islands. The Trobriands and Woodlark are too poorly represented in the database to show any significant relationships, but appear more closely related (30 species in common) than to any of the other island with an average of only 19 species connecting these two islands to the rest of the islands of the archipelago.

A better understanding of the interrelationships of the island floras must await more collecting and a more detailed study of the existing collections from the archipelago.

\section{ENDEMISM IN THE VASCULAR PLANTS}

So far 239 endemics have been described from the islands of the Milne Bay Archipelago (Appendix 1). Several genera show strong patterns of island speciation particularly the tree fern genus, Cyathea (Cyatheaceae), Anthorrhiza, Dolicholobium, Psychotria, and Hydnophytum (Rubiaceae), Freycinetia (Pandanaceae), Rhododendron and Vaccinium (Ericaceae), and Diospyros (Ebenaceae). The most diverse of the endemic genera is Myristica (Myristicaceae) with probably 9 endemic species. Syzygium (Myrtaceae) has 6 island endemics. Pandanus (Pandanaceae) has several endemic species but the status of some of the species is in doubt and they may be minor variants of more widely dispersed species. The endemic genus Rosselia requires more study as even its position in the Burseraceae has been questioned. The family Orchidaceae is very poorly represented in the database.

As the exploration of the islands intensifies we expect that the number of locally endemic species increases and the distribution patterns are extended, particularly to adjacent islands. Many undescribed species have already been collected, particularly in taxa that have not recently been revised. This includes undescribed taxa in Saurauia (Actinidiaceae) and Calamus (Aceraceae).

\section{RELATIONSHIPS OF THE FLORA}

Generally the flora of the archipelago is most closely related to the mainland of the Milne Bay Province. Several species including Livistona woodfordii Ridl. (Arecaceae) occur on the islands of the archipelago and in the Solomons. Other species occur on the Bismarck Archipelago and on the islands. Tabernae montana remota Leeuwenb. (Apocynaceae) is recorded also from Sulawesi (Middleton 2007: 388). This species is listed because of its very unusual distribution. Macaranga misimae Airy Shaw (Euphorbiaceae) is reported from 3 widely separate localities: Goodenough Island, the Eastern Highland of PNG and Biak Island in Papua. Macaranga tentaculata Airy Shaw (Euphorbiaceae) from Goodenough Island is known from a 'second' collection from the Bismarck Archipelago (Ridsdale NGF 30425) but this differs in having fruit tentacles almost glandless. Dactyliophora novae-guineae (F.M. Bailey) Danser (Loranthaceae) is disjunct to Cape York. Dendrobium atroviolaceum Rolfe (Orchidaceae) is known from two collections from South Queensland but these are probably cultivated in origins (Cribb pers. comm. 1982).

\section{CONCLUSIONS}

More collecting is urgently needed throughout the Milne Bay Archipelago to provide the basis for adequate conservation action, particularly in lowland areas threatened by the population explosion, and in the limestone and ultramafic areas with their distinctive floras. It is proposed to organize several expeditions 
to each of the islands of the Milne Bay Archipelago. A checklist of collections has been prepared for each island. These will be published separately after more detailed expeditions have been completed and additional collections identified and databased. The papers will include an historical account of the history of their botanical exploration, ecological notes, and conservation proposals,

Acknowledgements This study would not have been possible without the financial support of the Christensen Fund and the active support of the Botanical Research Institute of Texas, Fort Worth. Particularly I (RJ) wish to thank the Director, Dr Sy Sohmer, for his support. RJ also wish to thank Dr W. Baker of the Royal Botanic Gardens, Kew for his comments, particularly on Calamus, and for providing a check list of the New Guinea palms which resulted in several additions to the palms list. The staff of the National Herbarium in Lae and the Herbarium, Biology Department, University of Papua New Guinea have been very helpful. Jim Robbins of the National Research Institute in Port Moresby has provided an important 'back up' in assisting to deal with the issue of permits. In Alotau, Gretta Kwasnicka Todurawi has provided continuous support as have Ofara Petilionata, and the officers of Forestry Office: Andrew and Noel Dibela. The Milne Bay Provincial Research Committee has provided support in the issue of Provincial Research Permits.

\section{REFERENCES}

Annual Reports of British New Guinea. 1890-1904. Various papers: see Van Steenis-Kruseman, 1950.

Brass LJ. 1956. Results of the Archbold expeditions no 75. Summary of the Fourth Archbold expedition to New Guinea (1953). Bulletin of the American Museum of Natural History 111: 77-152, f. 1, pl. 10-21.

Frodin DG, Gressitt LJ. 1982. Biological exploration of New Guinea. In: Gressitt LJ (ed), Biogeography and ecology of New Guinea: 87-131. Junk, Boston, The Hague.

Middleton DJ. 2007. Apocynaceae. Flora Malesiana, Ser. I, Vol. 18: 1-471. Van Steenis-Kruseman MJ. 1950. Malaysian plant collectors and collections. Flora Malesiana, Ser. I, Vol. 1: 5-606.

Van Steenis-Kruseman MJ. 1955. Malaysian plant collectors and collections, Suppl. 1. Flora Malesiana, Ser. I, Vol. 5: 336.

Von Mueller F. 1892. Notes on botanical collections. Botanisches Centralblatt 50: 193-195.

Appendix 1 A provisional list of species endemic to the Milne Bay Archipelago or otherwise interesting.

Abbreviations: LTRF = Lowland Tropical Rainforest; LMF = Lower Montane Forest; MMF = Midmontane Forest; UMF = Upper Montane Forest. — G = Goodenough I.; F = Fergusson I.; $\mathrm{N}=$ Normanby I.; $\mathrm{M}=$ Misima I.; S = Sudest I.; R = Rossel I.; T = Trobriand I.; W = Woodlark I.

\section{FERNS}

\section{Cyatheaceae}

Cyathea glabberima Holttum 900-1400 m alt.; LMF; G F

Cyathea insulana Holttum (350-)750-1450 m alt.; LMF-MMF; G F N M R

Cyathea insularum Holttum 100-350 m alt.; LTRF; M S R W

Cyathea parvipinna Holttum 270 m alt.; LTRF; F N

\section{Elaphoglossaceae}

Elaphoglossum arachnoideum Holttum; 1600 m alt.; MMF-UMF; G

Elaphoglossum nesioticum Holttum; 1500-1600 m alt.; MMF-UMF; G

\section{Gleicheaceae}

Gleichenia deflexa Holttum; 800-850 m alt.; LMF; F G

\section{Grammitidaceae}

Grammitis curtipila Parris; 750-1600 m alt.; MMF; G F N

Oreogrammitis glossophylla (Parris) Parris; 760 m alt.; MMF; R

\section{Lindseaceae}

Lindsaea tetragona Kramer var. brassiana Kramer; 300 m alt.; LTRF; S

Lomariopsidaceae

Bolbitis novoguineensis Holttum; 250 and 900 m alt.; LMF-MMF; G S

Lomagramma brassii Holttum; 900 m alt.; LMF; G

Thelypteridaceae

Sphaerostephanos sudesticus Holttum; 2 m alt.; LTRF; S

Tectariaceae

Tectaria nesiotica Holttum; 950 m alt.; MMF; G

\section{Dicotyledons}

Apocynaceae

Alyxia graciliflora D.J.Middleton; 500-1400 m alt.; LMF-MMF; G S Micrechites grandiflorus (D.J.Middleton) D. J.Middleton; $10 \mathrm{~m}$ alt.; LTRF; R Tabernaemontana remota Leeuwenb.; 600-700 m alt., MMF; R (specimens from Sulawesi are also identified as this species (Middleton 2007: 388). Although not properly endemic, this species is listed because of its very unusual distribution and its conservation assessment as VU)

Araliaceae

Osmoxylon ellipsoideum Conn \& Frodin; $250 \mathrm{~m}$ alt.; LTRF; $\mathrm{N}$

Osmoxylon retribracteatum Conn \& Frodin; $0 \mathrm{~m}$ alt.; LTRF; $\mathrm{T}$

\section{Asclepiadaceae}

Hoya trigonolobos Schltr.; $0 \mathrm{~m}$ alt.; LTRF; $\mathrm{T}$

Marsdenia brassii P.I.Forst.; $300 \mathrm{~m}$ alt.; LMF; S

Marsdenia brunnea P.I.Forst.; $170 \mathrm{~m}$ alt.; LTRF; $\mathrm{N}$

Asteraceae

Gynura brassii Davies; 0 m alt.; LTRF; F N M

\section{Burseraceae}

Rosselia bracteata Forman; 10-80 m alt.; LTRF; R

Chrysobalanaceae

Hunga longifolia Prance; 300 m alt.; LMF; M

Clusiaceae

Calophyllum acutiputamen P.F.Stevens; 300 m alt.; LMF; R

Calophyllum goniocarpum P.F.Stevens; 150-700 m alt.; LTRF-MMF; M S

\section{Ebenaceae}

Diospyros benstonei Kosterm.; 30 m alt.; LTRF; M

Diospyros gillisonii Kosterm.; 0 m alt.; LTRF; M T

Diospyros normanbyensis Kosterm.; 15 m alt.; LTRF; N M

\section{Elaeocarpaceae}

Elaeocarpus meigei Weibel ssp. rosselensis Coode; 100-1025 m alt.; LTRF-MMF; R W

\section{Ericaceae}

Rhododendron comparabile Sleumer; 600-800 m alt.; MMF; S

Rhododendron goodenoughii Sleumer; 2000 m alt.; UMF; G

Rhododendron wrightianum Koord. var. insulare Sleumer; 820-1600 m alt.; LMF-UMF; G

Vaccinium carneolum Sleumer var. nesophilum Sleumer; 350 m alt.; LMF; M Vaccinium fraternum Sleumer; $1700 \mathrm{~m}$ alt.; MMF-UMF; G

Vaccinium homeoticum P.F.Stevens; 700-780 m alt.; MMF; S

\section{Euphorbiaceae}

Acalypha subintegra Airy Shaw; 0-27 m alt.; LTRF; T

Antidesma tagulae Airy Shaw; $60-450 \mathrm{~m}$ alt.; LTRF; S R

Aporusa misimiana Airy Shaw ex Schot; 60-450 m; LTRF; S R

Baccaurea nesophila Airy Shaw; 0-3 m alt.; (mangrove fringes); 350-510 m alt.; LMF; R

Baccaurea nesophila Airy Shaw var. microcarpa Airy Shaw; 200 m alt.; LTRF; S

Claoxylon goodenoviense Airy Shaw; 1500-1800 m alt.; UMF; G

Claoxylon salomonense Airy Shaw; 20-500 m alt.; LTRF-LMF; G (also in Solomons)

Cleistanthus normanbyensis Airy Shaw; 15-20 m alt.; LTRF; N

Codiaeum ludovicianum Airy Shaw var. Iudovicianum; (50-)100-700 m alt.;

LTRF-LMF; R

Codiaeum Iudovicianum Airy Shaw var. praeruptorum Airy Shaw; 0-20 m alt.; LTRF; R

Codiaeum ludovicianum Airy Shaw var. rheophytum Airy Shaw; 200-250 m alt.; LMF; S R

Glochidion intercastellanum Airy Shaw; 800-1500 m alt.; MMF-UMF; G N

Homalanthus goodenoviensis Airy Shaw; 900 m alt.; LMF; M

Homalanthus populifolius Airy Shaw; $20 \mathrm{~m}$ alt.; LTRF; M

Macaranga louisiadum Airy Shaw; 10-80 m alt.; LTRF; N S R (two collections from adjacent areas in Papua)

Macaranga misimae Airy Shaw; 250-350 m alt.; LTRF; G M (reported from widely separate localities: Goodenough and Misima Islands, the Eastern Highlands of PNG, and also Biak Island in Papua)

Macaranga tentaculata Airy Shaw; 800 m alt.; LMF; G (a second collection from the Bismarck Archipelago (Ridsdale NGF 30425) differs in having fruit tentacles almost glandless)

Mallotus Iullulae Airy Shaw; $100 \mathrm{~m}$ alt.; LTRF; W

Phyllanthus rosselensis Airy Shaw \& Webster; 20-50 m alt.; LTRF; R

Phyllanthus solomonenis Airy Shaw $\&$ Webster; $15 \mathrm{~m}$ alt.; LTRF; S (to Solomons)

Phyllanthus tangulae Airy Shaw \& Webster; 250 m alt.; LTRF; S

Flacourtiaceae

Homalium dentrecasteauxense Craven; 60 m alt., LTRF; N

\section{Gesneriaceae}

Agalmyle macrocolon R.R.Mill \& B.L.Burtt; 600-1000 m alt.; LMF-MMF; F N R

Boea hemsleyana B.L. Burtt; $300 \mathrm{~m}$ alt.; LTRF; R (also a single collection

from the Florida Islands, Solomons)

Boea niagethanica B.L.Burtt; $10 \mathrm{~m}$ alt.; LTRF; R

Boea rosselianum B.L.Burtt; $700 \mathrm{~m}$ alt.; MMF; R

Lamiaceae

Orthosiphon stamineus Benth.; 20 m alt; LTRF; 
Appendix 1 (cont.)

\section{Lauraceae}

Beilschmiedia novae-britannie Kosterm.; 100 m alt.; LTRF; W

Cinnamomum rosselianum Kosterm.; 700 m alt.; MMF; R

Cryptocarya rarinervia S.Moore; $50 \mathrm{~m}$ alt.; LTRF; $\mathrm{R}$

Cryptocarya tesselata Kosterm.; 50 m alt., LTRF; G

\section{Leguminosae}

Casearia macranthe Gilg; 300 m alt.; MF; LTRF; S

Dioclea hexandra (Ralph) Mabb.; 5-200 m alt.; LTRF; F S

\section{Loranthaceae}

Amyema brassii Barlow; 600-700 m alt.; MMF; S

Amyema subatiste Barlow; 600-700 m alt.; MMF; R

Dactyliophora novae-guineae (F.M.Bailey) Danser; 0-100 m alt.; LTRF; G

(disjunct to Cape York)

Sogerianthe cupuliformis Barlow; 5-150 m alt.; LTRF; G F S R

\section{Melastomataceae}

Astronidium muscosum Merr. \& L.M.Perry var. decurrens J.F.Maxwell;

300-700 m alt.; LTRF-LMF; S R

Astronidium sudestense J.F.Maxwell; $300 \mathrm{~m}$ alt.; LTRF; S

Astronidium variabile J.F.Maxwell var. variabile; 820-900 m alt.; LMF-MMF; N

Astronidium variabile J.F.Maxwell var. papillosum J.F.Maxwell; $350 \mathrm{~m}$ alt.;

LMF; M

Beccarianthus sp.; 50-840 m alt.; LTRF; S

Meliaceae

Xylocarpus rumphii $\mathrm{x}$ moluccensis (Lam.) M.Roem. sensu Mabb.; $0 \mathrm{~m}$ alt., LTRF; R

\section{Monimiaceae}

Kibara rosselensis Philipson; 700 m alt.; LMF; R

Kibara sudetensis Philipson; 700 m alt.; LMF; S

Levieria orientalis Philipson; 1500 m alt.; UMF; G

\section{Myristicaceae}

Horsfieldia tuberculata (K.Schum.) Warb. var. crassivalva W.J.de Wilde;

0-20 m alt.; LTRF; M S R (record from Solomons is doubtful)

Myristica incredibilus W.J. de Wilde; $10 \mathrm{~m}$ alt.; LTRF; R

Myristica inopinata Sinclair; 30-150 m alt.; LTRF; N (?) S

Myristica ovicarpa W.J.de Wilde; $200 \mathrm{~m}$ alt.; LTRF; R

Myristica polyantha W.J.de Wilde (1995) non. Boerl. (?1916); 300-1600 m alt.;

LMF-UMF; G S (collections from Sudest are possibly a distinct taxon)

Myristica rosselensis Sinclair var. rosselensis; 300 m alt.; LMF; M

Myristica rosselensis Sinclair var. minifolia W.J.de Wilde; $100-300 \mathrm{~m}$ alt.;

LTRF; S R

Myristica tenuivenia Sinclair ssp. tenuivenia; 10-150 m alt.; LTRF; M R

Myristica tenuivenia Sinclair ssp. lignosa W.J.de Wilde; 700-720 m alt.; MMF; F R

Myristica tristis Warb. subsp. louisiadensis W.J.de Wilde; $100-150 \mathrm{~m}$ alt.; LTRF; S R

\section{Myrsinaceae}

Ardisia brassiella B.C.Stone; 300-700 m alt.; MMF-UMF; R

Discocalyx sarcophylla Sleumer; 100-700 m alt.; LTRF-MMF; R

Fittingia carnosifloria Sleumer; 700-900 m alt.; LMF-MMF; F N

Maesa rufovillosa Mez; R

\section{Myrtaceae}

Decaspermum humile (G.Don) A.J.Scott; $15-200$ m alt., LTRF; S R

Eucalyptopsis aulauda Craven; 100-250 m alt., W

Syzygium luehmannii (F.Muell.) L.A.S. Johnson; 1000 m alt., MMF; G (sterile specimens from SE QId and NE NSW are doubtfully the same species)

Syzygium normanbiense T.G. Hartley \& L.M.Perry; $20 \mathrm{~m}$ alt.; LTRF; N

Syzygium waikaiunense T.G. Hartley \& L.M.Perry; 20-100 m alt.; LTRF; N

\section{Proteaceae}

Helicia insularis Foreman; 800-950 m alt.; MMF; F N R

Quintiniaceae

Quintinia insularis Gornall \& Al-Shammery; 720 m alt.; LMF; F

\section{Rubiaceae}

Amaracarpus uniflorus (K.Schum.) Davis var. humilis Davis; 250-1000 m alt.; LTRF-MMF; N

Amaracarpus uniflorus (K.Schum.) Davis var. uniflorus Davis; 15-900 m alt.; LTRF-MMF; G F N

Anthorhiza areolata Huxley; 600-750 m alt.; MMF; N

Anthorhiza bracteosa Huxley; 40-750 m alt.; LTRF-MMF; G F N W

Anthorhiza recurvispinna Huxley; 5-400 m alt.; LTRF-LMF; M S R

Calycosia kajewskii Merr. \& L.M.Perry; 10 m alt.; LTRF; W

Dolicholobium barbatum M.E.Jansen; 720-950 m alt.; MMF-UMF; F N

Dolicholobium cordatum M.E.Jansen; 50-700 m alt.; LMF; R

Dolicholobium longifructum M.E. Jansen; 300-500 m alt.; LMF; M W

Dolicholobium rheophilum M.E. Jansen; 15-30 m alt.; LTRF; R

Dolicholobium riuense M.E. Jansen; 250 m alt.; LTRF; M(?) S W

Hydnophytum auridemens Huxley \& Jebb; 300-400 m alt.; LTRF-LMF; M

Hydnophytum dentrecastense Huxley \& Jebb; 600-950 m alt.; MMF-UMF; N R

Hydnophytum sp. nov.; 400 m alt.; LMF; M

Hydnophytum sp. nov.; 400 m alt.; LTRF; $N$

Hydnophytum orichaleum Huxley \& Jebb; 100-500 m alt.; LTRF-LMF; S R

Hydnophytum rium Huxley \& Jebb; 300 m alt.; LMF; S R
Lasianthus hirsutus (Roxb.) Merr.; 250 m alt.; LTRF; S

Mussaenda pluviatilis S. Moore; 4-450 m alt.; LTRF-LMF; G F N

Myrmecodia albertisii Becc. subsp. dentrecastensis Huxley \& Jebb; $300 \mathrm{~m}$ alt.; LTRF; $M$

Myrmecodia albertisii Becc. subsp. incompta Huxley \& Jebb; 300-1830 m alt.; LTRF-MMF; G N M (the collection from Missima is anomalous and may be a distinct taxon)

Neonauclea glabra (Roxb.) Bakh.f. \& Ridsdale; 20 m alt.; LTRF; N

Psychotria goodenoughiensis Sohmer; 2-20 m alt.; LTRF; G S T

Psychotria reflexapedunculata Sohmer; 280-700 m alt.; LMF-MMF; R

Psychotria rosseliensis Sohmer; $700 \mathrm{~m}$ alt.; LMF; R

Xanthophytum grandiflorum Axelius; 250 m alt.; LTRF; S

Xanthophytum magnisepalum Axelius; 200-600 m alt.; LMF; R

\section{Rutaceae}

Acronychia normanbiensis T.G. Hartley; (20-)820-950 m alt.; LTRF-MMF; N

Acronychia trifoliolata Zoll. \& Moritzi var. trifoliolata; 20-50 m alt.; LTRF; R

('Rossel entity')

Melicope sudestica T.G.Hartley; 600-750 m alt.; MMF; S

Murraya crenulata (Turcz.) Oliv.; $10 \mathrm{~m}$ alt.; LTRF; W

Santalaceae

Dendromyza multinervis (Lawson) Meckl.; 200 m alt.; LTRF; S

Sapindaceae

Guioa misimaensis Welzen; 150 m alt.; LTRF; M

Guioa normanbyensis Welzen; 3-200 m alt.; LTRF; N

Mischocarpus bachnocarpus Radlk.; 200 m alt.; LTRF; N

Synima macrophylla Reyn.; 450 m alt.; LMF; N

Sapotaceae

Palaquium quecifolium (de Vriese) Burck; $10 \mathrm{~m}$ alt.; LTRF; T

Palaquium salomonense C.T.White; 20 m alt.; LTRF; N

Planchonella kaniensis (Krause) H.J.Lam; 400 m alt.; LTRF; N

Pouteria sp. nov. ; 900 m alt.; UMF; F

\section{Sterculiaceae}

Sterculia fanaiho Setch. subsp. pentamera Tantra; 5-15 m alt.; LTRF; M S

\section{Symplocaceae}

Symplocos cochinchinensis (Lour.) S. Moore var. tomentosa Noot.; 800 m alt.; UMF; F

Symplocos cochinchinensis (Lour.) S. Moore ssp. leptophylla (Brand) Noot.

var. insularis Noot.; G

Symplocos pulvinata Noot.; 865 m alt.; LTRF; N

Tiliaceae

Trichospermum heliotrichum Kosterm.; 250 m alt.; LTRF; S

\section{Monocotyledons}

\section{Araceae}

Cyrtosperma brassii A.Hay; 50-600 m alt.; LTRF-MMF; R

Cyrtosperma gressiflorum A. Hay; 150 m alt.; LTRF; R

\section{Arecaceae}

Heterospathe annectens H.E.Moore; $600 \mathrm{~m}$ alt.; LMF; S

Heterospathe pulchra H.E. Moore; $900 \mathrm{~m}$ alt.; MMF; F M

Ptychosperma burretianum Essig; 20-150 m alt.; LTRF; N

Ptychosperma ramosissimum Essig; 600-700 m alt.; LMF; R

Ptychosperma rosselense Essig; $700 \mathrm{~m}$ alt; LMF; R

Ptychosperma tagulense Essig; $600 \mathrm{~m}$ alt.; MMF; S

\section{Orchidaceae}

Dendrobium atroviolaceum Rolfe; 300-750 m alt.; LMF-MMF; F M S R (two collections from S Qld are probably cultivated in origin)

Mediocalcar versteeghii J.J.Sm. ssp. amphigeneum Schuit.; 600 m alt.; LMF; R

\section{Pandanaceae}

Freycinetia angusta Huynh; 1600 m alt.; UMF; G

Freycinetia awaiarensis Huynh; $950 \mathrm{~m}$ alt.; MMF; N

Freycinetia boluboluensis Huynh; 1400 m alt.; MMF; N

Freycinetia fergussoniensis Huynh; $720 \mathrm{~m}$ alt.; MMF; F

Freycinetia funicularis Merr. ssp. louisiadensis B.C.Stone; 330-850 m alt.;

LTRF-MMF; M S R

Freycinetia goodenoughensis (Sav. ex Lam.) Merr.; 1750 m alt.; UMF; G

Freycinetia lenifolia Huynh; 720 m alt.; MMF; G

Freycinetia louisiadensis Huynh; $650 \mathrm{~m}$ alt.; MMF; S R

Freycinetia misimica Huynh; $985 \mathrm{~m}$ alt.; MMF; M

Freycinetia normanbyensis Huynh; $450 \mathrm{~m}$ alt.; LMF; N

Freycinetia relegata Huynh; 90 m alt.; LTRF; R

Freycinetia rosseliana Huynh; $50 \mathrm{~m}$ alt.; LTRF; R

Freycinetia scabrida Huynh; 730 m alt.; UMF; R

Freycinetia woodlarkensis Huynh; $100 \mathrm{~m}$ alt.; LTRF; W

Pandanus alatus H.St. John; 0 m alt.; LTRF; S

Pandanus biciliatus H.St.John; 100 m alt.; LTRF; W

Pandanus galeatus H.St.John; $1600 \mathrm{~m}$ alt.; MMF; G

Pandanus luteus H.St.John; 1600 m alt.; MMF; G

Pandanus macgregorii Solms; F

Pandanus marginatus H.St.John non Roxb.; 15 m alt.; LTRF; G

Pandanus misimaensis H.St.John ex. B.C.Stone; $300 \mathrm{~m}$ alt.; LMF; M 